CENTRE FOR ECONOMIC PERFORMANCE

DISCUSSION PAPER NO. 278

TRADE UNIONS AND TRAINING PRACTICES

IN BRITISH WORKPLACES

February 1996

F. GREEN, S. MACHIN AND D. WILKINSON 


\begin{abstract}
We use establishment-level data from the 1991 Employers Manpower and Skills Practices Survey (EMSPS) and individual-level data from the Autumn 1993 Quarterly Labour Force Survey (QLFS) to investigate the links between training provision and workplace unionization. We focus on two training measures, an incidence variable and an intensity variable. Both are strongly positively related to whether unions are recognised in the workplace. Working in a unionized establishment substantially raises the probability of receiving training and the amount of training received by British workers. We view these results as confirming the potentially important role that British unions can play in developing skill formation.
\end{abstract}

This paper was produced as part of the Centre's

Programme on Industrial Relations 
TRADE UNIONS AND TRAINING PRACTICES

IN BRITISH WORKPLACES

F. GREEN, S. MACHIN AND D. WILKINSON

FEBRUARY 1996

Published by

Centre for Economic Performance

London School of Economics and Political Science

Houghton Street

London WC2A 2AE

CF. Green, S. Machin and D. Wilkinson 
ISBN 0753003155

\section{TRADE UNIONS AND TRAINING PRACTICES IN BRITISH WORKPLACES}

\section{Francis Green, Stephen Machin and David Wilkinson}

1. Introduction

2. Unions and Training: Theory and Existing Work

3. Data Description

4. Estimated Models of the Determinants of Training

5. Concluding Remarks 18

Endnotes $\quad 21$

Tables $\quad 23$

References $\quad 32$ 
The Centre for Economic Performance is financed by the Economic and Social Research Council. Francis Green is a Professor of Economics at the University of Leeds. Stephen Machin is a Dr of Economics at University College London and the Centre for Economic Performance, London School of Economics. David Wilkinson is a research assistant at the Centre for Economic Performance, London School of Economics.

\section{ACKNOWLEDGEMENTS}

Part of this paper draws on a report we produced in April 1995 for the Department of Employment entitled "Unions and Training: An Analysis of Training Practices in Unionized and Non-Unionized Workplaces". We are very grateful to the Department of Employment for financial support and to Louise Corcoran, Andrew Wareing and participants in a Centre for Economic Performance seminar for useful comments. We would also like to thank Steve Woodland for help with the EMSPS and WIRS data. 


\section{TRADE UNIONS AND TRAINING PRACTICES \\ IN BRITISH WORKPLACES}

\section{Francis Green, Stephen Machin and David Wilkinson}

\section{Introduction}

Many authors have emphasised the role that effective employee training can play in affecting worker productivity, wages and overall individual career development. This attention has varied from a focus on the effect of training on individual performance (eg the literature on the impact of training on wages ${ }^{1}$ ), to its impact on workplace and company performance (eg the National Institute matched plant studies ${ }^{2}$ ), through to comparisons of macroeconomic performance (eg studies which highlight training differences across countries and relate them to macroeconomic outcomes $^{3}$ ). Many governments now give a high priority to policies thought to stimulate training, either through direct interventions and subsidies of company training or through support for a "training market" via loan provision, dissemination of information about good practice and other measures.

Given the importance of training for economic performance, it seems important to understand what kinds of workplaces provide training for their workers. In particular, it has emerged from a variety of studies in many countries that the institutional environment in which businesses operate affects the process of skill formation in firms, and may interact with government policies (eg Streeck, 1989; CEDEFOP, 1987; Koike and Inoke, 1990). An important aspect of that environment is the character of employee relations in the organisation. In this paper we provide some evidence on this issue using British establishment- and individual-level data sources. While some of the main factors affecting company training are reasonably well known (Green, 1993b), at least as far as the 1980s are concerned, our principal focus is on one specific issue, about which relatively little is understood, namely are there any notable differences between training provision and receipt for individuals in union and nonunion workplaces?

There are several reasons why one should be interested in the relationship between trade unions and training practices. First, there is - in some circles - a perception that trade unions are bad for employee training, on the grounds that unions attempt to appropriate a share of any surplus generated by the firm's activities to finance the union wage premium: as such, they hinder the ability of firms to finance training practices by obtaining this wage gain. Second, when one considers recent aggregate patterns in the extent of training and in unionization they appear to move in opposite directions. Training in all forms has become a wider spread and more important form of company practice over the last ten years or so (see Table 1, below). On the other hand, unionization fell very sharply over the same time period. Whatever measure of union presence one chooses to focus on, there has been a sharp fall in union activity in the British labour market since its peak in 1979 (eg Disney, Gosling and Machin, 1995; and Millward et al, 1992). Could these opposing trends be related, with unions being seen as a constraint on skill formation which, once weakened, allowed training practices to expand?

A third reason, however, for being interested in the existence of a link between unions and training provision is that unions have, in recent years, attempted to place training issues high on their agenda. For example, Labour Research (1990) stated that, 
by 1990, a number of union officials claimed that they were either bargaining or consulting over training matters. The Trades Union Congress (1991) argued that training should form an important part of a new bargaining agenda for unions in the 1990s.

A fourth reason why the unions-training relation is worthy of study is that not all theoretical approaches unambiguously predict a negative union impact on training. There are plausible theoretical approaches that argue that the presence of unions may actually enhance worker training prospects and lead to improved productivity as compared to non-union workplaces. For instance, the collective voice approach of Freeman and Medoff (1984) argues that, as unions enhance communication channels within workplaces, this can encourage workers to accumulate longer job tenures (as they are less likely to quit) and, given higher within-employer career commitment, that employers are more likely to train workers. In the same vein, it is also possible that managers respond to the more formal environment that prevails in unionized workplaces to set up more formal procedures to identify training needs and this may lead to further training and a more sophisticated training infrastructure.

In the light of these remarks, we therefore intend to explore the empirical relationship between training and unionization. We present results drawn from two microeconomic data sources, the establishment-level Employers Manpower and Skills Practices Survey (EMSPS) of 1991 and the individual-level Labour Force Survey (LFS) of Autumn 1993. We present results that are very consistent across the two data sources. Unlike the predictions of the simple "unions as monopolies" approach, and despite the aggregate trends in training and union presence, we identify a strong positive association between the extent of training and unionization at the microeconomic level. As training is still rarely directly bargained over (see below) we interpret this positive association as reflecting the indirect influence that unions can exert on training, through voice effects and their ability to influence manager's actions. These results point to an important role that trade unions play in the process of skill formation for workers in British workplaces.

The structure of the rest of the paper is as follows. In Section 2 we briefly consider the theoretical routes via which trade unions may have an impact on training, and discuss related empirical work on the relationship between training and unionization. In Section 3 we describe the data sources that we use and present descriptive statistics on the key variables of interest. In Section 4 we present our estimates of the determinants of training from our two data sources. Finally, Section 5 concludes.

\section{Unions and Training: Theory and Existing Work Training and union bargaining}

In looking for an empirical association between training provision and unionization the first question that one might reasonably ask concerns the extent to which unions are actually able to bargain about training. Following the major upheavals of the 1980s British trade unions have been attempting to develop a new agenda for bargaining and consultation. This is especially the case, given the trends to decentralize bargaining, for issues negotiated at company- or establishment-level. One key feature of this new agenda is training. For example, by 1990 a number of union 
officials claimed to be either bargaining or consulting over training matters (Labour Research Department, 1990). The late 1980s saw major unions such as the Transport and General Workers' Union, the National Association of Local Government Officers, and Manufacturing, Science and Finance develop their own training initiatives in attempts to encourage their negotiators to discuss training agreements with employers. Influenced by these major players, and by the belief that improved training and consequent improved productive efficiency was crucial to the raising of living standards of union members, the Trades Union Congress announced that training should be an important aspect of a new bargaining agenda for trades unions for the 1990s (Trades Union Congress, 1991). The strategy involved negotiating minimum levels and standards of training, equal opportunities and close involvement in training decisions, if possible through workplace training committees. In the absence of favourable legislation, negotiators were to aim for voluntary agreements along the lines of proposed training models. It is probably too early to evaluate whether trade union strategies on training will succeed in placing training on the bargaining agenda widely across British industry. Whether it succeeds probably depends on many factors outside unions' direct control, in particular on the attitudes taken by companies themselves and on the public policy environment.

A detailed study of the ways in which some unions do get involved in training matters, and an evaluation of best practice in this area, was presented in a recent Employment Department report (Winterton and Winterton, 1994). But up to the first half of the present decade unions had not made large inroads. For the most part, management continues to regard training as an area for their own decision-making, independent of collective bargaining. The evidence for this comes on one hand from responses to the third Workplace Industrial Relations Survey, WIRS3, (Millward et al, 1992, p.255), which indicated that training had not been conceded as a bargaining issue in many places. A subsequent analysis of agreements reached during the 30 months following January 1991 showed relatively few such agreements containing provision for formal consultation over training and even fewer for bargaining over training levels or content (Claydon and Green, 1994). Nevertheless, there is some contrasting evidence that unions may be having an informal role in training matters in some workplaces, a role which may not always be recognised by management (Heyes, 1993; Stuart, 1994).

While trade unions' direct influence on the extent and nature of training is likely to have been relatively limited in recent years, this does not mean that their impact can be ignored. It is possible that their direct role will increase in the future, and for this reason it will be important to see how far unions, where they do have a role, actually increase training. Just as important is the indirect influence that unions have on training. Without necessarily bargaining directly over training, the presence of unions conditions the whole character of employee relationships in establishments. In theoretical terms, unions could thereby have either a positive or a negative impact on the extent of training in establishments.

In their simplest form, the case where the trade union acts as a monopolist in a competitive product market, formal union bargaining models predict that, because unions negotiate a wage that lies above the non-union wage, that they are likely to operate in workplaces that provide lower levels of training for their employees. ${ }^{4}$ Furthermore, even if one holds wages constant, it has long been argued that the 
existence of union induced job demarcations that permit unions to influence the ability of management to freely allocate tasks can provide a further brake on the incentives that managers have to engage in the training of their workers, again reinforcing any negative effect of trade unions on employee training.

It is evident that these arguments are somewhat simplistic for several reasons, and that the predictions can be altered if one adopts other approaches, ranging from small shifts to other models (eg moving away from the union monopoly model to an explicit bargaining approach) to much bigger moves away from it (eg to situations where unions actually directly bargain over training). It is useful to consider several such departures from the simple monopoly approach to see to what extent they can modify the prediction of a negative relationship between training practices and unionization.

In the simplest case unions could have a negative impact on training through their influence on pay. Empirical evidence for Britain does show that unions raise wages relative to the non-union sector, especially for manual workers (for example, Blanchflower, 1986, or Stewart, 1987, 1995), and this may discourage employers from paying for training courses. In particular, where unions raise the pay of younger workers, this reduces the incentive for firms to invest in their training, since the firms have to bear a higher cost and with young workers they are less likely to reap the longer-term benefits of the training as the workers move to other firms. Ryan (1991) has shown that one reason why unions might pursue a policy of raising wages for younger workers rather than a policy of raising training is that it is difficult for unions to monitor the quality of training provided, especially when much of the training is onthe-job and uncertified. In the context of the United States Mincer (1983) has argued that, in addition, where unions impose "seniority rules" for promotions to higher grades, this reduces individual's incentives to invest in training.

On the other hand, unions could have a positive impact of training through their influence on channels of communication and management and through them to the level of employee turnover. Unions provide a "voice" for individual grievances and for contributions towards productive efficiency that would often not be available for individual employees (Freeman and Medoff, 1984). In so far as this reduces labour turnover, (and there is empirical evidence for this in Britain, for example, Elias, 1994), there is likely to be a longer period to reap the benefits of investments in training, and therefore a larger return. Where unions have an influence in an establishment, employees may also feel more secure, and therefore less threatened by the changes in work practices that often accompany training courses. Managers may also respond to the more formal environment that is engendered by unions being present, by setting up more formal procedures for identifying training needs and defining skill levels as required by pay formulas. From all these points of view, it is arguable that the presence of active trade unions in the workplace may lead both to a greater level of training and to a more developed training infrastructure within the establishment and the company. ${ }^{5}$ Against this background, it is therefore of great interest to know which of the above effects prevails in practice.

\section{Existing work}


Existing empirical evidence is, rather like the predictions of different theoretical models, somewhat mixed. Some US work (see, inter alia, Duncan and Stafford, 1980, or Mincer, 1983) points to a negative union impact on training. However, even in the US, some more recent work challenges this finding. Once one differentiates between different forms of training one can obtain negative and positive training effects: Lynch (1992), for example, reports a positive coefficient on union variables in probit models of on-the-job training and a negative (and statistically insignificant) union coefficient in an off-the-job training probit; Veum (1995) considers seven different forms of training (two on-the-job, five off-the-job) and obtains positive (and significant) coefficients on a union variable in probit models of the determinants of on-the-job training (company training and apprenticeships) and statistically insignificant (one positive, four negative) coefficients on the union variable in the off-the-job training equations. In an establishment-level study, Osterman (1995) finds a significant positive effect of union presence on formal off-the-job training.

Existing research for Britain in this area is limited, but the consensus supports the view that overall trade unions tend to increase participation in training. Green (1993a) reports a positive significant union coefficient in a training participation equation based on 1989 Labour Force Survey data for workers in small workplaces (<25 employees) and an insignificant coefficient in an equation for workers in larger workplaces. Booth (1991) uses data from the 1987 British Social Attitudes Survey and reports a positive effect of the presence of a workplace union on training receipt for both men and women. And Greenhalgh and Mavrotas (1994) also report positive union coefficients in their logit training models based on the Individuals Study of the Training in Britain survey.

On balance, therefore, the British work seems to point to a potentially important positive link between training provision and union presence. In our view, however, the existing studies, whilst very useful, do have a number of shortcomings (principally due to data limitations). The data sources that we have available mean that we can redress a number of these drawbacks. First, as the existing work concentrates only on individual-based data, there is typically relatively limited information about the nature of industrial relations at workplaces, including what type of union is active if at all, and whether there is a closed shop operating. Moreover, it is also known that some forms of training, in particular apprenticeship, are interpreted differently by employees and employers, so that it will be of interest in our establishment-level work to see whether training, as defined by the employers who actually provide it, is influenced by employee relations systems.

The second shortcoming is that the previous analyses have, in the absence of anything better, taken union membership as the measure of unionism. Yet membership is only an imperfect measure of the extent of union activity (Disney, Gosling and Machin, 1995). A few employees may choose to join unions even though the union is not recognised for negotiating purposes by the establishments where they work. More important, there are many employees for whom pay and conditions are effectively negotiated by a union but who choose not to become members. For this reason, a measure of whether a union is recognised for some bargaining purposes is likely to be a superior measure of unionism. One indication of why this may be important comes from an establishment-based study of unions and training in Australia (Kennedy et al, 
1994). There, also, it was found that trade unions had a positive impact on training, but the measure of unionism mattered. Where, simply, the proportion of union members at a plant was used as the measure of unionism, no effect was found. But, where unionism was measured by whether unions were actively bargaining at the establishment, the impact was substantial.

Finally, the third shortcoming of the previous studies is that, while they examined the effect on the probability of receiving any training, it may also be important to know the effect on the amount of training received by those who do receive it. It is possible, for example, that unionism could have an impact in one direction on the probability of receiving training but an impact in the opposite direction on the quantity received. ${ }^{6}$

\section{Data Description}

\section{Recent trends in the extent of training and unionization}

Table 1 reports aggregate trends in training provision and unionization in Britain between 1984 and 1994. It is very clear that the Labour Force Survey data onjob-related training points to a very marked increase in the extent of training of the British workforce between 1984 and 1994. In 1984 about 8.3\% of workers reported that they had received some form of job-related training in the four weeks before the interview date; by 1994 this had risen to $14.2 \%$. The bulk of this increase was concentrated into the 1984 to 1990 time period (the relevant percentage receiving job-related training in 1990 being $14.4 \%)$.

The remainder of the Table considers trends in unionization. These have been well documented before (Metcalf, 1991; Disney, Gosling and Machin, 1995; Corcoran and Wareing, 1994). There has been a very sharp decline in unionization among the British labour force, which reflects a parallel decline in trade union influence at both company level and at national and sectoral levels. For example, the density of union membership, defined as the proportion of employees in unions, was $58 \%$ in 1980 but by 1993 had fallen to about 35\%. The same pattern emerges for other definitions of union status (eg union recognition or coverage: see Disney, Gosling and Machin, 1995).

\section{The Employers' Manpower and Skills Practices Survey}

The Employers' Manpower and Skills Practices Survey (EMSPS) was set up to examine aspects of employers' skill formation, including their skill needs, recruitment practices and training. It was conducted as a follow up to the 1990 Workplace Industrial Relations Survey (WIRS3) which is a nationally representative survey of 2061 British establishments with 25 or more employees in all sectors except agriculture, forestry and fishing and coal mining.

All WIRS3 main management respondents who said they did not mind being recontacted were asked to participate in EMSPS. Once unproductive and out of scope responses were taken into account the EMSPS sample was left at 1693 establishments, corresponding to a response rate of $89 \%$. Face-to-face interviews were then conducted by experienced interviewers employed by Social and Community Planning Research (SCPR) between November 1990 and October 1991 using a structured questionnaire.

Initial analysis of the EMSPS dataset was carried out in a series of Employment Department Working Papers (Dench 1993a, 1993b and 1993c) and concerned itself with 
types of employer providing training, training infrastructure and aspects of continuous training. Dench (1993a) found that $97 \%$ of the workplaces in the survey had provided some training for at least some of their employees during the previous year, and that $85 \%$ non-training workplaces employed less than 50 employees whilst no non-trainers employed more than 500 employees. Workplaces which were small, single site firms or part of a small organisation were least likely to have provided any training as were workplaces in the construction and metal goods sectors.

\section{The Quarterly Labour Force Survey (QLFS)}

The second data set which we analyse is the Autumn 1993 Quarterly Labour Force Survey (QLFS). For the first time in that quarter, respondents were asked a set of questions designed to find out if they worked at an establishment where a union was recognised for bargaining purposes. This information can then be matched against the training data and other variables in the data set to investigate the influence of trade union recognition at individual-level in Britain.

The QLFS is directed at a sample of about 60,000 responding households in Great Britain every quarter (with a sample from Northern Ireland being added in Spring). It covers private households plus students and NHS workers living in residential accommodation. South of the Caledonian canal an unclustered random sample is taken from the Postal Address File, while north of the canal households are drawn from the public telephone directory. Households enter the sample in waves of about 12,000 and remain within it for five quarters. The response rate for households entering in Spring 1992 was 78\%. First interviews are carried out face to face, but subsequent interviews are done on the telephone. We restrict our analysis of these data to employees only and exclude the Armed Forces.

\section{Econometric Methodology \\ Training incidence}

As the discussion of the data sources makes clear, we pitch our analysis at two levels, establishment- and individual-level. For an economic agent $(\mathrm{i}=$ establishment, $\mathrm{j}=$ individual) one can think of modelling the probability that the agent provides/receives training in a simple discrete choice framework and estimate probit models of training provision/receipt. These are defined as follows:

$$
\begin{array}{r}
\mathrm{P}_{\mathrm{i}}^{*}=\mathrm{X}_{\mathrm{i}}^{\prime} \beta+\gamma \mathrm{U}_{\mathrm{i}}+\mathrm{u}_{\mathrm{i}} \\
\text { where } \mathrm{P}_{\mathrm{i}}=1 \text { if } \mathrm{P}_{\mathrm{i}}^{*} \geq 0 \\
\mathrm{P}_{\mathrm{i}}=0 \text { otherwise }
\end{array}
$$




$$
\begin{gathered}
\pi_{j}^{*}=Z_{j}^{\prime} \delta+\lambda U_{i}+e_{j} \\
\text { where } \pi_{j}=1 \text { if } \pi_{j}^{*} \geq 0 \\
\pi_{j}=0 \text { otherwise }
\end{gathered}
$$

where we only observe the discrete (0-1) indicators of training receipt, $P_{\mathrm{i}}$ and $\pi_{\mathrm{j}}$, and not the underlying latent dependent variables (with the * superscripts). In (1) U denotes union status in the establishment (and thus has an i subscript in both equations), $X$ and $Z$ contain the other determinants of training that we consider (described below) and $u$ and e are random error terms.

In these models one can define $\operatorname{Pr}\left[\mathrm{P}_{\mathrm{i}}=1\right]$ as the probability that an establishment trains its workers and $\operatorname{Pr}\left[\pi_{\mathrm{j}}=1\right]$ as the probability an individual receive training and obtain the union impact on training (the marginal effect) as follows:

$$
\begin{aligned}
& \operatorname{Pr}\left[\mathrm{P}_{\mathrm{i}}=1 \mid \mathrm{U}_{\mathrm{i}}=1\right]-\operatorname{Pr}\left[\mathrm{P}_{\mathrm{i}}=1 \mid \mathrm{U}_{\mathrm{i}}=0\right]=\Phi\left[\mathrm{X}_{\mathrm{i}}^{\prime} \beta+\gamma\right]-\Phi\left[\mathrm{X}_{\mathrm{i}}^{\prime} \beta\right] \\
& \operatorname{Pr}\left[\pi_{\mathrm{j}}=1 \mid \mathrm{U}_{\mathrm{i}}=1\right]-\operatorname{Pr}\left[\pi_{\mathrm{j}}=1 \mid \mathrm{U}_{\mathrm{i}}=0\right]=\Phi\left[\mathrm{Z}_{\mathrm{j}}^{\prime} \delta+\lambda\right]-\Phi\left[\mathrm{Z}_{\mathrm{j}}^{\prime} \delta\right]
\end{aligned}
$$

where $\Phi$ is the standard normal distribution function. The marginal impact of $U$ can thus be computed by evaluating these probability differences at certain values of $X$ or $\mathrm{Z}$ : as we are interested in the conceptual experiment that conducts a ceteris paribus union/non-union comparison we evaluate at union means. ${ }^{7}$

To draw an appropriate ceteris paribus comparison we need to control for other factors that may determine training incidence and which may also differ by union status (ie properly specify the $\mathrm{Xs}$ and $\mathrm{Zs}$ ). In the establishment-level work the following controls were included: a set of dummy variables for establishment size; the proportion of employees in the establishment of the occupation under consideration; a dummy variable for private or public sector; the proportion of employees in the establishment who are not white; the proportion of females in the establishment; the proportion of part-timers in the establishment; a dummy variable for whether the establishment faced any skill shortages in the last twelve months; the local labour market unemployment rate; a dummy variable for whether the establishment faced five or fewer competitors; eight (1-digit) industry dummy variables; and ten regional dummy variables.

In the individual-level work the following controls were included: whether the individual worked full-time or part-time; whether the individual worked in the public or private sector; whether their job was permanent or temporary; whether they were 
male or female; their marital status; their level of educational qualification; length of current job tenure and work experience; and a set of industry, occupation and regional controls.

\section{Training intensity}

One of the most attractive features of both surveys that we use is that they contain more information than simple incidence measures and it is therefore possible to compute training intensity measures. The two that we consider are:

$$
\text { Establishment-level intensity }=\mathrm{P}_{\mathrm{i}} \cdot \mathrm{D}_{\mathrm{i}}
$$

\section{Individual-level intensity $=1_{j} \cdot h_{j}$}

where $D_{i}$ is the average number of days training received over the last year for workers in establishment $i, l_{j}$ is whether an individual received training in the last week and $h_{j}$ is the hours of training received. One should note, as a result of the nature of the LFS question structure, that the individual intensity measure is a weekly measure, whilst the incidence measure described above corresponds to the last four weeks.

It is clear that these training intensity measures are censored so we use a tobit estimator to deal with the censoring. These models allow for the fact that some establishments do not provide any training for particular employees and that some individuals have zero hours of training. The same set of control variables was used for this analysis as described above. The marginal union/non-union differences are calculated in a similar way (ie by switching on and off the union recognition dummy variable, $\mathrm{U}_{\mathrm{i}}$ ) to that described above for training provision. ${ }^{8}$

\section{Descriptive statistics}

Table 2 reports a set of descriptive statistics on training incidence and intensity from EMSPS and QLFS. The statistics are broken down by union recognition status in all cases, and are reported separately for manual and non-manual employees. The definitions of training incidence are: $P_{\mathrm{i}}$, whether or not an establishment trained any of its (manual or non-manual) workers in the last twelve months; and $\pi_{\mathrm{j}}$, whether or not an individual received training in the last four weeks. In the raw data both $P_{i}$ and $\pi_{j}$ are (significantly) higher in unionized workplaces: in EMSPS 76\% of unionized workplaces provided training for manual workers, as compared to $50 \%$ of non-union workplaces (comparable percentages for non-manuals are $91 \%$ and $72 \%$ ); in the QLFS $8 \%$ of manual workers in unionized workplaces received training in the last four weeks, as compared to $6.5 \%$ in non-union workplaces (for non-manuals the percentages were $22 \%$ and $13 \%$ respectively). 
Turning to intensity, this is again higher in unionized situations. Average training intensity in EMSPS, defined as average days trained per worker $\mathrm{P}_{\mathrm{i}} \mathrm{D}_{\mathrm{i}}$, is 2.3 days for manuals and 3.9 days for non-manuals in the union sector and 1.9 days for manuals and 2.0 days for non-manuals in the non-union sector. In QLFS, where training intensity is average hours training received in the last week, intensity is also higher in the union sector, for both manuals and non-manuals. In sum, these simple descriptive statistics indicate that there is a substantially greater amount of training participation and greater training intensity in the union sector than in the non-union sector.

\section{Estimated Models of the Determinants of Training The incidence of training}

We begin our econometric analysis by considering some simple probit models of the determinants of training incidence, at establishment-level for the EMSPS and at individual-level for the LFS. These are reported in Table 3 (3a reports equations for manual workers, $3 \mathrm{~b}$ for non-manuals). Three specifications are reported in each case, the first being a simple probit regression of training incidence on union recognition only, the second including a set of establishment-level or individual-level controls, and the third adding a set of industry and regional dummy variables. A marginal union effect, calculated as described in equation (2) above, is reported in the bottom row of the Table.

In all the reported models the estimated coefficient on the union recognition variable is positive and statistically significant. Once one controls for other determinants of training incidence, the establishment-level EMSPS data suggests that unionized establishments are some 16 to $17 \%$ more likely to provide training for manual workers in the year preceding the survey; they are about $8 \%$ more likely to have provided training for non-manual workers. In the individual-level QLFS equations manual workers in unionized workplaces are about $1.5 \%$ more likely to have received training in the four weeks preceding the survey; non-manual workers are about 5\% more likely to have received such training if they work in a unionized workplace. ${ }^{9}$ According to both these data sources there is strong evidence of a positive link between training provision and workplace unionization.

The estimated coefficients on the other control variables seem reasonable. According to EMSPS, training incidence is more likely for manuals and non-manuals the bigger is the establishment, the bigger the appropriate occupational share of employment, the fewer female workers employed in the establishment and if there are any skill shortages. Whether the establishment is in the public sector, faces fewer than five competitors and the ethnic mix of employment all have insignificant coefficients. In the individual QLFS models, individuals are more likely to receive training in larger workplace, if they have more educational qualifications, if they are skilled (for manuals) or professionals (for non-manuals), if they work full-time (non-manuals) and if they work in the public sector (for non-manuals). The other controls seem less important. These findings are broadly consistent with earlier research on training determinants in Britain (Green, 1993b). 


\section{The intensity of training}

Table 4 reports a set of tobit estimates of training intensity equations. The structure of the Table is the same as for Table 3, with 4a reporting manual equations and $4 \mathrm{~b}$ non-manual equations. In the models that incorporate the control variables the estimated coefficient on the union recognition variable is always positive and statistically significant. In the EMSPS models unionized establishments provide about 1.1 days extra training over the year before the survey for manual workers as compared to non-union establishments. For non-manuals, about 1 day extra training is provided. In the QLFS models manual workers employed in unionized workplaces received about 0.17 hours additional training in the previous week, whilst non-manuals received about 0.20 hours extra. Hence, the models of Table 3 and 4 provide strong evidence that unions are associated with both a higher frequency and intensity of training in British workplaces.

\section{More detailed union effects}

As noted above, the data sources that we use, especially the EMSPS data, enable us to consider the nature of the estimated union effects in more detail. Table 5 reports a set of further experiments which re-specify the training equations in a number of ways (5a reports the incidence experiments, whilst $5 \mathrm{~b}$ reports the intensity models). The first row of the upper panel of the Table simply reproduces the basic union recognition effect from Tables 3 and 4 . We use these as the benchmark for comparison purposes in the remainder of the Table.

We considered two ways of specifying more detailed union effects. The first focuses on situations where one expects the union wage gain to be larger, and the second considers a possibility for union voice effects. Considering the first of these, existing evidence suggests that British unions raise wages by more (ie achieve a higher union non-union wage differential) in the presence of closed shop arrangements (Stewart, 1987, 1995) and where there are multiple unions who bargain separately (Machin, Stewart and Van Reenen, 1993). According to the simple union monopoly approaches discussed in Section 2 above one would therefore expect to see lower training activity in situations where these bigger wage gains occur. In Table 5 we thus breakdown the basic union recognition effect by single/multiple union status and by whether or not there is a union membership arrangement or UMA (a UMA is defined as the presence of closed shop arrangements or, given the outlawing of the closed shop by 1990 , where management recommends union membership ${ }^{10}$ ). There is no evidence for a reduced training impact where unions raise wages by more: in all cases we cannot reject the null hypothesis of equal coefficients for single/multiple and UMA/no UMA establishments.

The second set of experiments breaks down the union coefficient by whether or not the establishment has any employee involvement schemes (EI) or a joint consultative committee (JCC). We view these as indicating improved communication channels and, as such, a measure of collective voice within the workplace. According to the specifications in Table 5 the union impact on training is always highest where a union is recognised and there is a JCC or EI. For manual workers the coefficient is significantly higher in both the incidence and intensity equations. Hence, there seems to be some important evidence that unionized establishments with better 
communication channels are more likely to provide training. We view this as evidence in line with an indirect positive union influence on training via collective voice type mechanisms.

As noted above in Section 2 some work on unions and training has found their impact to be confined to smaller workplaces (Green, 1993). Despite the fact that EMSPS only covers establishments with at least 25 workers we considered potential heterogeneity in the estimated union effect by stratifying the union effect into three size bands (25-99 employees, 100-249 employees and 250+ employees). With one exception (the intensity equation for non-manuals) one cannot reject the null of no variation in the union effect by size class. Probably more interesting on size variations are the QLFS equations as the QLFS data does contain workplaces of all sizes. When we breakdown the union effect by size ( $<25$ and $25+$ employees) we do find a bigger effect in the smaller workplaces, and the gap is statistically significant in three of the four reported models. However, despite this evidence of a bigger impact in smaller workplaces (see the marginal effects in the Table) the union impact remans positive and statistically significant in the larger workplaces, thereby reinforcing the importance of the estimated union effects.

\section{Other training measures}

It would be consistent with the hypothesis that unions have their positive effect through providing a collective voice, if unions also have a positive relationship to formal training strategies and infrastructures, and we are fortunate that the EMSPS survey contains further rich details regarding training practices in British workplaces. A large number of questions regarding training were asked (see Dench, 1993a, 1993b, 1993c; or Green, Machin and Wilkinson, 1995, for more details). Table 6 considers the relationship between three additional training variables and unionization by reporting probit models of whether the organisation of which the establishment is part has a training centre, a training budget or a training plan which cover the establishment. The models all include the same controls as used in the most detailed earlier EMSPS equations (ie also including region and industry controls). The results again provide more evidence for a positive association between the extent of training practices and unionization. The estimated coefficients on the union variable are all positive and are significantly different from zero in the training centre and training plan equations. The marginal effects suggest that unionized workplaces are $17 \%$ and $11 \%$ more likely to have a training centre and a training plan as compared to non-union workplaces.

\section{Concluding Remarks}

This paper considers the relationship between the incidence and extent of training and union presence using establishment- and individual-level data in the early 1990s. On the whole it presents strong evidence that unionized workers are more likely to participate in training, for both manual and non-manual workers, and that, given participation, they are also more likely to receive more training. This is true of raw data descriptions from the establishment-level Employers' Manpower and Skills Practices Survey of 1991 and from the individual-level Autumn 1993 Labour Force Survey, and from econometric models that control for other determinants of training. These effects, moreover, are quite large. Our point estimates suggest that the impact of 
unionization on average days training is 0.17 (manual and 0.20 (non-manual) hours per-week, based on the individual-level data, or about 1 day per year, based on the establishment-level data. These are not inconsiderable when compared to existing averages, namely 0.2 (manual) and 1.2 (non-manual) hours per week, or 2.1 (manual) and 2.7 (non-manual) days per year. These findings suggest that the rise in training that occurred in Britain must have occurred despite the downward trend in unionization.

Given that, at the time of the surveys, the direct role of unions in training matters appears limited, the results should perhaps be interpreted more as reflecting their indirect influence. The presence of unions is likely to influence channels of communication and management behaviour as unions provide a "voice" both for individual grievances and contributions to productive efficiency (Freeman and Medoff, 1984). It is probably also true that their presence is likely to make employees feel more secure, and less threatened by changes in work practices that sometimes accompany training. Labour turnover will then be lower in such workplaces (Elias, 1994) allowing for a longer period over which the benefits of training may be reaped. There may also be a more formal environment in unionised workplaces allowing for better identification of training needs.

An interesting question that remains is whether the (continuing) fall in union presence will have an impact on training participation and volume in future years and whether the skills problems regularly cited by British employers will be exacerbated by this fall. The results in this paper suggest that, despite past falls in aggregate membership, unions still have a potentially important role to play in the skill formation process in British workplaces. This role could be enlarged if unions succeed in their objectives of playing a more direct role in bargaining over training. As we have seen, the extent of the direct role that unions play in training strategy is less than clear. It remains the case that management tends to regard training as an area for their own decision making (Millward et al, 1992; Claydon and Green, 1994), but there is some evidence that unions may have a direct but informal role in training matters in some workplaces (Heyes, 1993; Stuart, 1994). It is possible that the direct role of unions in training matters will increase in the future, and this is clearly an aim of the Trades Union Congress and several large unions. Whatever that outcome, the findings here suggest that the size of the union sector in the future could have a notable influence on the extent of human capital formation in the British economy. 


\section{ENDNOTES}

1. There is a large body of work on the relationship between labour market earnings and training. Most of this work regresses log wages on a training indicator to test the simple prediction of human capital theory that training raises wages. Some recent examples based on US data are Lynch (1992) and Veum (1995); a recent British example is Blundell, Dearden and Meghir (1995).

2. There has been a large research agenda at the National Institute of Economic and Social Research which compares workers in similar workplaces across different European countries. A recent example is Mason, Prais and van Ark (1992).

3. See, among others, Finegold and Soskice (1988) or Crouch (1992).

4. The argument is a simple one. Suppose there are two forms of costs, wage costs $(\mathrm{W})$ and training costs $(\mathrm{t})$ both defined per worker, and the employer has $\mathrm{L}$ workers. Profits will be $\Pi(W, t, L)=R(L)-W . L-t . L$, where $R($.$) is the firm revenue function. If$ unions raise $W$ then, in the absence of any offsetting productivity effects working through $R(L)$, to stay in business unionised firms will have to spend less on training.

5. These theoretical arguments are set out in more detail in Claydon and Green (1994) and in Kennedy et al (1994).

6. Although Arulampalam, Booth and Elias (1995) do use counts of the number of times that individuals received training based on longitudinal data from the National Child Development Survey. Interestingly, they obtain a positive coefficient on a union membership variable in their count data models.

7. In practice we could choose any values for $X_{i}$ or $Z_{4}$ (ie we face the usual index number issue in comparisons of this kind). We have also considered overall sample means and non-union means to evaluate these difference and find the overall results are robust to this choice. The choice to evaluate these probabilities at the mean for unionised establishments provides us with a very simple interpretation of any union/non-union difference. It can be thought of as the effect of taking away union recognition, whilst holding constant all other factors, from a typical establishment that has a recognised union.

8. For a tobit model of training intensity (I) defined (dropping the subscripts for convenience) $I^{*}=X^{\prime} b+c U+v$, where $I^{*}=I$ for $I>0$ and $I^{*}=0$ for $I=0$, the marginal union effect is computed as $\left.\Phi\left(\left(\mathrm{X}^{\prime} \mathrm{b}+\mathrm{c}\right) / \sigma\right)\left[\mathrm{X}^{\prime} \mathrm{b}+\mathrm{c}+\sigma \mathrm{M}^{\mathrm{u}}\right]-\Phi\left(\mathrm{X}^{\prime} \mathrm{b}\right) / \sigma\right)\left[\mathrm{X}^{\prime} \mathrm{b}+\sigma \mathrm{M}^{\mathrm{n}}\right]$ where $\sigma$ is the

estimated standard error of the tobit regression, $\Phi$ is the standard normal distribution function, $\phi$ is the normal density function and $\mathrm{M}^{\mathrm{k}}(\mathrm{k}=\mathrm{u}, \mathrm{n})$ is the appropriate Mill's ratio term $\left(\mathrm{u}=\right.$ union, $\mathrm{n}=$ non-union) defined as $\mathrm{M}^{\mathrm{u}}=\phi\left(\left(\mathrm{X}^{\prime} \mathrm{b}+\mathrm{c} / \sigma\right) / \Phi\left(\left(\mathrm{X}^{\prime} \mathrm{b}+\mathrm{c} / \sigma\right)\right.\right.$ and $\mathrm{M}^{\mathrm{n}}=\phi\left(\left(\mathrm{X}^{\prime} \mathrm{b} / \sigma\right) / \Phi\left(\left(\mathrm{X}^{\prime} \mathrm{b} / \sigma\right)\right.\right.$. 
9. We also estimated a probit model of training receipt in the week preceding the survey (including the same controls as in column (6) of Table 3) and obtained qualitatively similar results. For manuals the estimated coefficient (standard error) on the union recognition variable was .150 (.047) with an associated marginal effect of .009; for non-manuals the coefficient estimate (standard error) was .153 (.025) and the marginal effect was .026.

10. We view the management recommends membership group as 'de facto' closed shops: see Machin and Stewart (1996) for more discussion. 


\section{TABLE 1}

\section{Aggregate Trends in the Extent of Training and Unionization}

\begin{tabular}{|c|c|c|c|c|}
\hline & $\begin{array}{l}\text { Proportion of } \\
\text { Employees of } \\
\text { Working Age } \\
\text { Receiving Job- } \\
\text { Related } \\
\text { Training in } \\
\text { Last Four } \\
\text { Weeks (LFS }{ }^{1} \text { ) }\end{array}$ & $\begin{array}{l}\text { Aggregate } \\
\text { Union } \\
\text { Density } \\
\text { (Proportion } \\
\text { of Workers } \\
\text { That are } \\
\text { Union } \\
\text { Members) }\end{array}$ & $\begin{array}{l}\text { Proportion of } \\
\text { Establishments } \\
\text { with Manual } \\
\text { Union } \\
\text { Recognition }\end{array}$ & $\begin{array}{l}\text { Proportion of } \\
\text { Establishments } \\
\text { with Non- } \\
\text { Manual Union } \\
\text { Recognition }\end{array}$ \\
\hline 1984 & .083 & .44 & .61 & .50 \\
\hline 1985 & .095 & .43 & & \\
\hline 1986 & .098 & .41 & & \\
\hline 1987 & .108 & .41 & & \\
\hline 1988 & .123 & .40 & & \\
\hline 1989 & .135 & .39 & & \\
\hline 1990 & .144 & .38 & .48 & .43 \\
\hline 1991 & .138 & .37 & & \\
\hline 1992 & .134 & .36 & & \\
\hline 1993 & .134 & .35 & & \\
\hline 1994 & .142 & .33 & & \\
\hline $\begin{array}{l}\text { Change, } \\
\text { 1984-1994 }\end{array}$ & .059 & -.11 & & \\
\hline $\begin{array}{l}\text { Change, } \\
\text { 1984-1990 }\end{array}$ & .061 & -.06 & -.13 & -.07 \\
\hline
\end{tabular}

Notes:

1. $\quad$ Source for training data: Annual LFS 1984-1991; Spring Quarter QLFS 19921994.

2. Source for union density data: 1984-87 - Waddington (1992); 1988 - Bird (1990) for membership numbers and Employment Gazette, May 1990, for employment; 1989-94 - LFS/QLFS.

3. Source for union recognition data: Millward et al (1992). 
Descriptive Statistics

\begin{tabular}{|c|c|c|c|c|c|c|c|}
\hline & \multicolumn{4}{|c|}{ EMSPS } & \multicolumn{3}{|r|}{ L } \\
\hline & Definition & Union & $\begin{array}{l}\text { Non- } \\
\text { Union }\end{array}$ & $\begin{array}{l}\text { Union Non-Union } \\
\text { Gap (Standard } \\
\text { Error) }\end{array}$ & Definition & Union & Non-U \\
\hline \multicolumn{8}{|l|}{ Manual Workers } \\
\hline Incidence & $\mathrm{P}_{\mathrm{i}}$ & 0.755 & 0.499 & $.255(.026)$ & $\pi_{j}$ & .079 & .065 \\
\hline Sample size & & 822 & 558 & & & 8568 & 8407 \\
\hline Intensity & $\mathrm{P}_{\mathrm{i} \cdot} \cdot \mathrm{D}_{\mathrm{i}}$ & 2.318 & 1.895 & $.423(.447)$ & $1_{j} \cdot h_{j}$ & .700 & .595 \\
\hline Sample size & & 589 & 386 & & & 8578 & 8503 \\
\hline Intensity for Trainers & {$\left[\mathrm{P}_{\mathrm{i}} \cdot \mathrm{D}_{\mathrm{i}}\right] \mid \mathrm{P}_{\mathrm{i}}=1$} & 3.376 & 3.458 & $-.083(.664)$ & {$\left[1_{j} \cdot h_{j j}\right] \mid 1_{j}=1$} & 16.428 & 14.810 \\
\hline Sample size & & 460 & 213 & & & 359 & 335 \\
\hline \multicolumn{8}{|l|}{ Non-Manual Workers } \\
\hline Incidence & $\mathrm{P}_{\mathrm{i}}$ & 0.907 & 0.721 & $.185(.021)$ & $\pi_{i}$ & .217 & .125 \\
\hline Sample size & & 834 & 559 & & & 17004 & 16954 \\
\hline Intensity & $\mathrm{P}_{\mathrm{i} \cdot} \cdot \mathrm{D}_{\mathrm{i}}$ & 3.909 & 1.973 & $1.936(.332)$ & $h_{i}$ & 1.451 & .989 \\
\hline Sample size & & 594 & 418 & & & 17056 & 17157 \\
\hline Intensity for Trainers & {$\left[\mathrm{P}_{\mathrm{i}} \cdot \mathrm{D}_{\mathrm{i}}\right] \mid \mathrm{P}_{\mathrm{i}}=1$} & 4.480 & 3.196 & $1.284(.408)$ & {$\left[1_{j} \cdot h_{j_{j}}\right] \mid 1_{j}=1$} & 12.291 & 13.365 \\
\hline Sample size & & 529 & 301 & & & 2004 & 1258 \\
\hline
\end{tabular}

Notes: $\quad$ 1. i denotes establishment, $\mathrm{j}$ denotes individual.

2. $\mathrm{P}_{\mathrm{i}}=1$ if provided training in last 12 months, 0 otherwise.

3. $\pi_{\mathrm{j}}=1$ if received training in last 4 weeks, 0 otherwise.

4. $\mathrm{l}_{\mathrm{j}}=1$ if received training in last week, 0 otherwise.
5. $\mathrm{D}_{\mathrm{i}}=$ average numb in last 12 months.

6. $h_{j}=$ average numbe in last week.

7. All weighted by W 


\begin{tabular}{|c|c|c|c|c|c|c|c|}
\hline & \multicolumn{3}{|c|}{ EMSPS $^{1}$} & \multicolumn{4}{|c|}{ QLFS $^{2}$} \\
\hline & $(1)$ & (2) & (3) & & (4) & (5) & (6) \\
\hline Constant & $\begin{array}{c}0.040 \\
(0.053) \\
\end{array}$ & $\begin{array}{l}-0.617 \\
(0.167) \\
\end{array}$ & $\begin{array}{l}-0.840 \\
(0.271) \\
\end{array}$ & Constant & $\begin{array}{l}-1.525 \\
(0.021) \\
\end{array}$ & $\begin{array}{l}-1.516 \\
(0.064) \\
\end{array}$ & $\begin{array}{l}-1.308 \\
(0.080) \\
\end{array}$ \\
\hline $\begin{array}{l}\text { Manual Union } \\
\text { Recognition }\end{array}$ & $\begin{array}{c}0.847 \\
(0.073) \\
\end{array}$ & $\begin{array}{c}0.475 \\
(0.099) \\
\end{array}$ & $\begin{array}{l}0.499 \\
(0.104) \\
\end{array}$ & Manual Union Recognition & $\begin{array}{c}0.109 \\
(0.029) \\
\end{array}$ & $\begin{array}{c}0.121 \\
(0.038) \\
\end{array}$ & $\begin{array}{c}0.139 \\
(0.039) \\
\end{array}$ \\
\hline $\begin{array}{l}\text { Manual Share of } \\
\text { Employment }\end{array}$ & & $\begin{array}{l}1.479 \\
(0.142) \\
\end{array}$ & $\begin{array}{l}1.624 \\
(0.170) \\
\end{array}$ & Skilled Manual & & $\begin{array}{l}0.183 \\
(0.036) \\
\end{array}$ & $\begin{array}{c}0.205 \\
(0.037) \\
\end{array}$ \\
\hline Public Sector & & $\begin{array}{l}-0.145 \\
(0.105) \\
\end{array}$ & $\begin{array}{l}-0.054 \\
(0.161)\end{array}$ & Public Sector & & $\begin{array}{c}0.183 \\
(0.042) \\
\end{array}$ & $\begin{array}{c}0.079 \\
(0.050) \\
\end{array}$ \\
\hline $\begin{array}{l}\text { Female Share of } \\
\text { Employment }\end{array}$ & & $\begin{array}{l}-0.910 \\
(0.236) \\
\end{array}$ & $\begin{array}{l}-0.737 \\
(0.258) \\
\end{array}$ & Female & & $\begin{array}{l}-0.001 \\
(0.043) \\
\end{array}$ & $\begin{array}{l}-0.031 \\
(0.046) \\
\end{array}$ \\
\hline $\begin{array}{l}\text { Part-time Share of } \\
\text { Employment }\end{array}$ & & $\begin{array}{c}0.512 \\
(0.185) \\
\end{array}$ & $\begin{array}{c}0.169 \\
(0.222) \\
\end{array}$ & Work Part-time & & $\begin{array}{c}0.042 \\
(0.051) \\
\end{array}$ & $\begin{array}{l}-0.005 \\
(0.053) \\
\end{array}$ \\
\hline $\begin{array}{l}\text { Non-White Share of } \\
\text { Employment }\end{array}$ & & $\begin{array}{l}0.005 \\
(0.030) \\
\end{array}$ & $\begin{array}{l}-0.002 \\
(0.037)\end{array}$ & Married & & $\begin{array}{l}-0.063 \\
(0.038) \\
\end{array}$ & $\begin{array}{l}-0.061 \\
(0.038)\end{array}$ \\
\hline $\begin{array}{l}\text { Skill Shortage in } \\
\text { Establishment }\end{array}$ & & $\begin{array}{l}0.135 \\
(0.089) \\
\end{array}$ & $\begin{array}{l}0.197 \\
(0.093) \\
\end{array}$ & Potential Experience & & $\begin{array}{l}-0.038 \\
(0.005) \\
\end{array}$ & $\begin{array}{l}-0.040 \\
(0.005) \\
\end{array}$ \\
\hline $\begin{array}{l}\text { Fewer than Five } \\
\text { Competitors }\end{array}$ & & $\begin{array}{c}0.013 \\
(0.103) \\
\end{array}$ & $\begin{array}{c}0.064 \\
(0.109) \\
\end{array}$ & $\begin{array}{l}\text { Potential Experience } \\
\text { Squared }\end{array}$ & & $\begin{array}{c}0.0004 \\
(0.0001) \\
\end{array}$ & $\begin{array}{c}0.0005 \\
(0.0001) \\
\end{array}$ \\
\hline $\begin{array}{l}\text { Establishment with 50- } \\
99 \text { Employees }\end{array}$ & & $\begin{array}{c}0.239 \\
(0.133) \\
\end{array}$ & $\begin{array}{l}0.262 \\
(0.139) \\
\end{array}$ & Temporary Employment & & $\begin{array}{c}0.040 \\
(0.063)\end{array}$ & $\begin{array}{c}0.045 \\
(0.063) \\
\end{array}$ \\
\hline $\begin{array}{l}\text { Establishment with } \\
\text { 100-199 Employees }\end{array}$ & & $\begin{array}{c}0.288 \\
(0.133) \\
\end{array}$ & $\begin{array}{c}0.289 \\
(0.138) \\
\end{array}$ & Job Tenure & & $\begin{array}{c}0.0001 \\
(0.0002) \\
\end{array}$ & $\begin{array}{c}0.0002 \\
(0.0002) \\
\end{array}$ \\
\hline $\begin{array}{l}\text { Establishment with } \\
\text { 200-499 Employees }\end{array}$ & & $\begin{array}{c}0.390 \\
(0.142) \\
\end{array}$ & $\begin{array}{c}0.414 \\
(0.148) \\
\end{array}$ & Degree & & $\begin{array}{c}0.717 \\
(0.124) \\
\end{array}$ & $\begin{array}{c}0.668 \\
(0.124) \\
\end{array}$ \\
\hline $\begin{array}{l}\text { Establishment with } \\
\text { 500-999 Employees }\end{array}$ & & $\begin{array}{l}0.550 \\
(0.167) \\
\end{array}$ & $\begin{array}{c}0.631 \\
(0.171) \\
\end{array}$ & Further Education & & $\begin{array}{c}0.807 \\
(0.078) \\
\end{array}$ & $\begin{array}{c}0.754 \\
(0.078) \\
\end{array}$ \\
\hline \multirow{6}{*}{$\begin{array}{l}\text { Establishment with } \\
1000 \text { or more } \\
\text { Employees }\end{array}$} & & $\begin{array}{l}1.098 \\
(0.177)\end{array}$ & $\begin{array}{l}1.211 \\
(0.183)\end{array}$ & A Level & & $\begin{array}{c}0.544 \\
(0.059)\end{array}$ & $\begin{array}{c}0.513 \\
(0.059)\end{array}$ \\
\hline & & & & Apprenticeship & & $\begin{array}{c}0.366 \\
(0.050) \\
\end{array}$ & $\begin{array}{c}0.346 \\
(0.050) \\
\end{array}$ \\
\hline & & & & O Level & & $\begin{array}{c}0.521 \\
(0.054) \\
\end{array}$ & $\begin{array}{c}0.506 \\
(0.054) \\
\end{array}$ \\
\hline & & & & CSE & & $\begin{array}{c}0.285 \\
(0.063) \\
\end{array}$ & $\begin{array}{c}0.278 \\
(0.063) \\
\end{array}$ \\
\hline & & & & Other Qualification & & $\begin{array}{c}0.261 \\
(0.062) \\
\end{array}$ & $\begin{array}{c}0.246 \\
(0.062) \\
\end{array}$ \\
\hline & & & & $\begin{array}{l}\text { Workplace Size >25 } \\
\text { employees }\end{array}$ & & $\begin{array}{c}0.076 \\
(0.038) \\
\end{array}$ & $\begin{array}{c}0.074 \\
(0.039) \\
\end{array}$ \\
\hline $\begin{array}{l}\text { Industry \& Region } \\
\text { Dummies }\end{array}$ & No & No & Yes & $\begin{array}{l}\text { Industry \& Region } \\
\text { Dummies }\end{array}$ & No & No & Yes \\
\hline Log-Likelihood & -783.0 & -582.9 & -557.7 & Log-Likelihood & -4346.8 & -3942.2 & -3914.0 \\
\hline Sample size & 1380 & 1224 & 1224 & Sample size & 16975 & 16790 & 16790 \\
\hline $\begin{array}{l}\text { Mean of Dependent } \\
\text { Variable }\end{array}$ & 0.606 & 0.613 & 0.613 & $\begin{array}{l}\text { Mean of Dependent } \\
\text { Variable }\end{array}$ & 0.072 & 0.072 & 0.072 \\
\hline Marginal Union Effect & 0.297 & 0.164 & 0.171 & Marginal Union Effect & 0.015 & 0.014 & 0.015 \\
\hline
\end{tabular}

Notes: $1 . \quad$ Dependent variable is whether any training was provided for manual employees in the last year.

2. Dependent variable is whether any training was received by manual employees in the last four weeks. 


\begin{tabular}{|c|c|c|c|c|c|c|c|}
\hline & \multicolumn{3}{|c|}{ EMSPS $^{1}$} & \multicolumn{4}{|c|}{ QLFS $^{2}$} \\
\hline & $(1)$ & (2) & (3) & & $(4)$ & (5) & (6) \\
\hline Constant & $\begin{array}{c}0.784 \\
(0.059) \\
\end{array}$ & $\begin{array}{l}-0.023 \\
(0.161) \\
\end{array}$ & $\begin{array}{l}-0.583 \\
(0.298) \\
\end{array}$ & Constant & $\begin{array}{l}-1.148 \\
(0.012) \\
\end{array}$ & $\begin{array}{l}-1.239 \\
(0.046) \\
\end{array}$ & $\begin{array}{l}-1.101 \\
(0.054) \\
\end{array}$ \\
\hline $\begin{array}{l}\text { Non-Manual Union } \\
\text { Recognition }\end{array}$ & $\begin{array}{c}0.627 \\
(0.087) \\
\end{array}$ & $\begin{array}{c}0.393 \\
(0.122) \\
\end{array}$ & $\begin{array}{c}0.434 \\
(0.128) \\
\end{array}$ & $\begin{array}{l}\text { Non-Manual Union } \\
\text { Recognition }\end{array}$ & $\begin{array}{c}0.364 \\
(0.016) \\
\end{array}$ & $\begin{array}{c}0.199 \\
(0.021) \\
\end{array}$ & $\begin{array}{l}0.199 \\
(0.022) \\
\end{array}$ \\
\hline $\begin{array}{l}\text { Non-Manual Share of } \\
\text { Employment }\end{array}$ & & $\begin{array}{l}1.546 \\
(0.207) \\
\end{array}$ & $\begin{array}{l}2.003 \\
(0.254) \\
\end{array}$ & Professional Worker & & $\begin{array}{l}0.046 \\
(0.020) \\
\end{array}$ & $\begin{array}{l}0.058 \\
(0.020) \\
\end{array}$ \\
\hline Public Sector & & $\begin{array}{l}0.009 \\
(0.144)\end{array}$ & $\begin{array}{l}0.197 \\
(0.194)\end{array}$ & Public Sector & & $\begin{array}{l}0.209 \\
(0.021)\end{array}$ & $\begin{array}{c}0.111 \\
(0.029)\end{array}$ \\
\hline $\begin{array}{l}\text { Female Share of } \\
\text { Employment }\end{array}$ & & $\begin{array}{l}-0.133 \\
(0.258)\end{array}$ & $\begin{array}{l}-0.256 \\
(0.288)\end{array}$ & Female & & $\begin{array}{l}0.031 \\
(0.019) \\
\end{array}$ & $\begin{array}{c}0.010 \\
(0.020)\end{array}$ \\
\hline $\begin{array}{l}\text { Part-time Share of } \\
\text { Employment }\end{array}$ & & $\begin{array}{l}0.297 \\
(0.201)\end{array}$ & $\begin{array}{c}0.154 \\
(0.260) \\
\end{array}$ & Part-time & & $\begin{array}{l}-0.154 \\
(0.023) \\
\end{array}$ & $\begin{array}{l}-0.148 \\
(0.024)\end{array}$ \\
\hline $\begin{array}{l}\text { Non-White Share of } \\
\text { Employment }\end{array}$ & & $\begin{array}{l}-0.022 \\
(0.036)\end{array}$ & $\begin{array}{l}-0.053 \\
(0.044) \\
\end{array}$ & Married & & $\begin{array}{l}-0.086 \\
(0.020)\end{array}$ & $\begin{array}{l}-0.087 \\
(0.020)\end{array}$ \\
\hline $\begin{array}{l}\text { Skill Shortage in } \\
\text { Establishment }\end{array}$ & & $\begin{array}{l}0.200 \\
(0.109)\end{array}$ & $\begin{array}{l}0.291 \\
(0.117) \\
\end{array}$ & Potential Experience & & $\begin{array}{l}-0.012 \\
(0.003)\end{array}$ & $\begin{array}{l}-0.013 \\
(0.003)\end{array}$ \\
\hline $\begin{array}{l}\text { Fewer than Five } \\
\text { Competitors }\end{array}$ & & $\begin{array}{l}-0.205 \\
(0.109) \\
\end{array}$ & $\begin{array}{l}-0.199 \\
(0.119) \\
\end{array}$ & $\begin{array}{l}\text { Potential Experience } \\
\text { Squared }\end{array}$ & & $\begin{array}{c}0.00001 \\
(0.00005)\end{array}$ & $\begin{array}{r}0.00000 \\
(0.00006) \\
\end{array}$ \\
\hline $\begin{array}{l}\text { Establishment with } \\
\text { 50-99 Employees }\end{array}$ & & $\begin{array}{l}0.190 \\
(0.145)\end{array}$ & $\begin{array}{c}0.183 \\
(0.152)\end{array}$ & $\begin{array}{l}\text { Temporary } \\
\text { Employment }\end{array}$ & & $\begin{array}{c}0.003 \\
(0.034)\end{array}$ & $\begin{array}{l}-0.005 \\
(0.034) \\
\end{array}$ \\
\hline $\begin{array}{l}\text { Establishment 100-199 } \\
\text { Employees }\end{array}$ & & $\begin{array}{l}0.312 \\
(0.151) \\
\end{array}$ & $\begin{array}{l}0.292 \\
(0.157) \\
\end{array}$ & Job Tenure & & $\begin{array}{l}-0.0004 \\
(0.0001) \\
\end{array}$ & $\begin{array}{l}-0.0004 \\
(0.0001)\end{array}$ \\
\hline $\begin{array}{l}\text { Establishment 200-499 } \\
\text { Employees }\end{array}$ & & $\begin{array}{l}0.506 \\
(0.164) \\
\end{array}$ & $\begin{array}{c}0.534 \\
(0.172) \\
\end{array}$ & Degree & & $\begin{array}{l}0.568 \\
(0.041) \\
\end{array}$ & $\begin{array}{c}0.526 \\
(0.042) \\
\end{array}$ \\
\hline $\begin{array}{l}\text { Establishment 500-999 } \\
\text { Employees }\end{array}$ & & $\begin{array}{l}0.545 \\
(0.195) \\
\end{array}$ & $\begin{array}{l}0.658 \\
(0.206) \\
\end{array}$ & Further Education & & $\begin{array}{c}0.644 \\
(0.041) \\
\end{array}$ & $\begin{array}{c}0.613 \\
(0.041) \\
\end{array}$ \\
\hline \multirow{6}{*}{$\begin{array}{l}\text { Establishment with } \\
1000 \text { or more } \\
\text { Employees }\end{array}$} & & $\begin{array}{l}1.227 \\
(0.260)\end{array}$ & $\begin{array}{l}1.415 \\
(0.278)\end{array}$ & A Level & & $\begin{array}{c}0.491 \\
(0.041)\end{array}$ & $\begin{array}{c}0.468 \\
(0.041)\end{array}$ \\
\hline & & & & Apprenticeship & & $\begin{array}{c}0.272 \\
(0.044) \\
\end{array}$ & $\begin{array}{c}0.258 \\
(0.045) \\
\end{array}$ \\
\hline & & & & O Level & & $\begin{array}{c}0.349 \\
(0.039) \\
\end{array}$ & $\begin{array}{c}0.328 \\
(0.040) \\
\end{array}$ \\
\hline & & & & CSE & & $\begin{array}{l}0.137 \\
(0.052) \\
\end{array}$ & $\begin{array}{c}0.125 \\
(0.052) \\
\end{array}$ \\
\hline & & & & Other Qualification & & $\begin{array}{l}0.328 \\
(0.052)\end{array}$ & $\begin{array}{c}0.307 \\
(0.052) \\
\end{array}$ \\
\hline & & & & $\begin{array}{l}\text { Workplace Size >25 } \\
\text { Employees }\end{array}$ & & $\begin{array}{l}0.037 \\
(0.020) \\
\end{array}$ & $\begin{array}{c}0.045 \\
(0.020) \\
\end{array}$ \\
\hline $\begin{array}{l}\text { Industry \& Region } \\
\text { Dummies }\end{array}$ & No & No & Yes & $\begin{array}{l}\text { Industry \& Region } \\
\text { Dummies }\end{array}$ & No & No & Yes \\
\hline Log-Likelihood & -522.7 & -411.4 & -389.6 & Log-Likelihood & -15280.2 & -14384.2 & -14350.9 \\
\hline Sample size & 1393 & 1226 & 1226 & Sample size & 33958 & 33314 & 33314 \\
\hline $\begin{array}{l}\text { Mean of Dependent } \\
\text { Variable }\end{array}$ & 0.803 & 0.799 & 0.799 & $\begin{array}{l}\text { Mean of Dependent } \\
\text { Variable }\end{array}$ & 0.171 & 0.173 & 0.173 \\
\hline Marginal Union Effect & 0.137 & 0.077 & 0.082 & Marginal Union Effect & 0.091 & 0.052 & 0.051 \\
\hline
\end{tabular}

Notes: $1 . \quad$ Dependent variable is whether any training was provided for non-manual employees in the last year.

2. Dependent variable is whether any training was received by non-manual employees in the last four weeks. 


\begin{tabular}{|c|c|c|c|c|c|c|c|}
\hline & \multicolumn{3}{|c|}{ EMSPS $^{1}$} & \multicolumn{4}{|c|}{ QLFS $^{2}$} \\
\hline & (1) & (2) & (3) & & $(4)$ & (5) & (6) \\
\hline Constant & $\begin{array}{l}-1.286 \\
(0.439)\end{array}$ & $\begin{array}{l}-1.396 \\
(1.220)\end{array}$ & $\begin{array}{l}0.246 \\
(1.762)\end{array}$ & Constant & $\begin{array}{l}-68.732 \\
(2.598)\end{array}$ & $\begin{array}{l}-55.246 \\
(3.277)\end{array}$ & $\begin{array}{l}-50.668 \\
(3.752)\end{array}$ \\
\hline $\begin{array}{l}\text { Manual Union } \\
\text { Recognition }\end{array}$ & $\begin{array}{l}1.835 \\
(0.542)\end{array}$ & $\begin{array}{l}2.510 \\
(0.686)\end{array}$ & $\begin{array}{l}2.370 \\
(0.709)\end{array}$ & $\begin{array}{l}\text { Manual Union } \\
\text { Recognition }\end{array}$ & $\begin{array}{l}1.375 \\
(1.334)\end{array}$ & $\begin{array}{l}5.637 \\
(1.578)\end{array}$ & $\begin{array}{l}6.475 \\
(1.624)\end{array}$ \\
\hline $\begin{array}{l}\text { Manual Share of } \\
\text { Employment }\end{array}$ & & $\begin{array}{l}2.357 \\
(1.008)\end{array}$ & $\begin{array}{l}2.846 \\
(1.121)\end{array}$ & Skilled Manual & & $\begin{array}{l}5.487 \\
(1.492)\end{array}$ & $\begin{array}{l}6.372 \\
(1.534)\end{array}$ \\
\hline Public Sector & & $\begin{array}{l}-2.157 \\
(0.692)\end{array}$ & $\begin{array}{l}-1.401 \\
(0.998)\end{array}$ & Public Sector & & $\begin{array}{l}2.451 \\
(1.804)\end{array}$ & $\begin{array}{l}0.142 \\
(2.146)\end{array}$ \\
\hline $\begin{array}{l}\text { Female Share of } \\
\text { Employment }\end{array}$ & & $\begin{array}{l}-3.322 \\
(1.616)\end{array}$ & $\begin{array}{l}-3.846 \\
(1.741)\end{array}$ & Female & & $\begin{array}{l}-1.326 \\
(1.757)\end{array}$ & $\begin{array}{l}-2.085 \\
(1.845)\end{array}$ \\
\hline $\begin{array}{l}\text { Part-time Share of } \\
\text { Employment }\end{array}$ & & $\begin{array}{l}2.811 \\
(1.198)\end{array}$ & $\begin{array}{l}0.136 \\
(1.374)\end{array}$ & Work Part-time & & $\begin{array}{l}4.489 \\
(2.016) \\
\end{array}$ & $\begin{array}{l}3.489 \\
(2.084) \\
\end{array}$ \\
\hline $\begin{array}{l}\text { Non-White Share of } \\
\text { Employment }\end{array}$ & & $\begin{array}{l}0.230 \\
(0.210)\end{array}$ & $\begin{array}{l}0.395 \\
(0.249)\end{array}$ & Married & & $\begin{array}{l}-1.530 \\
(1.625)\end{array}$ & $\begin{array}{l}-1.402 \\
(1.630)\end{array}$ \\
\hline $\begin{array}{l}\text { Skill Shortage in } \\
\text { Establishment }\end{array}$ & & $\begin{array}{l}0.410 \\
(0.594)\end{array}$ & $\begin{array}{l}0.682 \\
(0.598) \\
\end{array}$ & Potential Experience & & $\begin{array}{l}-1.742 \\
(0.197) \\
\end{array}$ & $\begin{array}{l}-1.766 \\
(0.198) \\
\end{array}$ \\
\hline $\begin{array}{l}\text { Fewer than Five } \\
\text { Competitors }\end{array}$ & & $\begin{array}{l}-0.978 \\
(0.660)\end{array}$ & $\begin{array}{l}-0.570 \\
(0.678)\end{array}$ & $\begin{array}{l}\text { Potential Experience } \\
\text { Squared }\end{array}$ & & $\begin{array}{c}0.022 \\
(0.004) \\
\end{array}$ & $\begin{array}{l}0.022 \\
(0.004)\end{array}$ \\
\hline $\begin{array}{l}\text { Establishment with 50- } \\
99 \text { Employees }\end{array}$ & & $\begin{array}{l}-1.151 \\
(0.976)\end{array}$ & $\begin{array}{l}-1.180 \\
(0.966)\end{array}$ & $\begin{array}{l}\text { Temporary } \\
\text { Employment }\end{array}$ & & $\begin{array}{l}1.204 \\
(2.453)\end{array}$ & $\begin{array}{l}1.301 \\
(2.461)\end{array}$ \\
\hline $\begin{array}{l}\text { Establishment with 100- } \\
199 \text { Employees }\end{array}$ & & $\begin{array}{l}-1.049 \\
(0.979) \\
\end{array}$ & $\begin{array}{l}-1.204 \\
(0.971) \\
\end{array}$ & Job Tenure & & $\begin{array}{l}-0.010 \\
(0.009) \\
\end{array}$ & $\begin{array}{l}-0.009 \\
(0.009) \\
\end{array}$ \\
\hline $\begin{array}{l}\text { Establishment with 200- } \\
499 \text { Employees }\end{array}$ & & $\begin{array}{l}-0.719 \\
(0.994) \\
\end{array}$ & $\begin{array}{l}-0.616 \\
(0.993)\end{array}$ & Degree & & $\begin{array}{l}17.323 \\
(5.106)\end{array}$ & $\begin{array}{l}16.103 \\
(5.110)\end{array}$ \\
\hline $\begin{array}{l}\text { Establishment with 500- } \\
999 \text { Employees }\end{array}$ & & $\begin{array}{l}0.018 \\
(1.079) \\
\end{array}$ & $\begin{array}{l}0.700 \\
(1.078) \\
\end{array}$ & Further Education & & $\begin{array}{l}19.636 \\
(3.368) \\
\end{array}$ & $\begin{array}{l}18.366 \\
(3.377) \\
\end{array}$ \\
\hline \multirow[t]{6}{*}{$\begin{array}{l}\text { Establishment with } 1000 \\
\text { or more Employees }\end{array}$} & & $\begin{array}{l}-0.611 \\
(1.075) \\
\end{array}$ & $\begin{array}{l}-0.082 \\
(1.072)\end{array}$ & A Level & & $\begin{array}{l}15.497 \\
(2.491) \\
\end{array}$ & $\begin{array}{l}14.633 \\
(2.495) \\
\end{array}$ \\
\hline & & & & Apprenticeship & & $\begin{array}{l}10.278 \\
(2.170) \\
\end{array}$ & $\begin{array}{l}9.477 \\
(2.179) \\
\end{array}$ \\
\hline & & & & O Level & & $\begin{array}{l}15.096 \\
(2.260) \\
\end{array}$ & $\begin{array}{l}14.787 \\
(2.269) \\
\end{array}$ \\
\hline & & & & CSE & & $\begin{array}{l}7.683 \\
(2.628) \\
\end{array}$ & $\begin{array}{l}7.543 \\
(2.633) \\
\end{array}$ \\
\hline & & & & Other Qualification & & $\begin{array}{l}6.852 \\
(2.747) \\
\end{array}$ & $\begin{array}{l}6.572 \\
(2.764) \\
\end{array}$ \\
\hline & & & & $\begin{array}{l}\text { Workplace Size >25 } \\
\text { employees }\end{array}$ & & $\begin{array}{l}1.761 \\
(1.560) \\
\end{array}$ & $\begin{array}{l}2.143 \\
(1.601) \\
\end{array}$ \\
\hline $\begin{array}{l}\text { Industry \& Region } \\
\text { Dummies }\end{array}$ & No & No & Yes & $\begin{array}{l}\text { Industry \& Region } \\
\text { Dummies }\end{array}$ & No & No & Yes \\
\hline Log-Likelihood & -2524.6 & -2253.1 & -2227.8 & Log-Likelihood & -5503.0 & -5137.8 & -5123.5 \\
\hline Sample size & 975 & 874 & 874 & Sample size & 17081 & 16893 & 16893 \\
\hline $\begin{array}{l}\text { Mean of Dependent } \\
\text { Variable }\end{array}$ & 2.080 & 2.133 & 2.133 & $\begin{array}{l}\text { Mean of Dependent } \\
\text { Variable }\end{array}$ & 0.647 & 0.643 & 0.643 \\
\hline Marginal Union Effect & 0.882 & 1.170 & 1.113 & $\begin{array}{l}\text { Marginal Union } \\
\text { Effect }\end{array}$ & 0.056 & 0.154 & 0.169 \\
\hline
\end{tabular}

Notes: 1. Dependent variable is the proportion of manual employees receiving training in the last year multiplied by the average number of days training they received.

2. Dependent variable is the number of hours training received in the last week 


\begin{tabular}{|c|c|c|c|c|c|c|c|}
\hline & \multicolumn{3}{|c|}{ EMSPS $^{1}$} & \multicolumn{4}{|c|}{ QLFS $^{2}$} \\
\hline & (1) & (2) & (3) & & (4) & (5) & (6) \\
\hline Constant & $\begin{array}{l}0.900 \\
(0.307) \\
\end{array}$ & $\begin{array}{l}-1.102 \\
(0.758)\end{array}$ & $\begin{array}{l}-0.573 \\
(1.282) \\
\end{array}$ & Constant & $\begin{array}{l}-40.839 \\
(0.770) \\
\end{array}$ & $\begin{array}{l}-36.102 \\
(1.532) \\
\end{array}$ & $\begin{array}{l}-33.075 \\
(1.750) \\
\end{array}$ \\
\hline $\begin{array}{l}\text { Non-Manual Union } \\
\text { Recognition }\end{array}$ & $\begin{array}{l}1.410 \\
(0.393) \\
\end{array}$ & $\begin{array}{l}1.520 \\
(0.499) \\
\end{array}$ & $\begin{array}{l}1.706 \\
(0.516) \\
\end{array}$ & $\begin{array}{l}\text { Non-Manual Union } \\
\text { Recognition }\end{array}$ & $\begin{array}{l}6.815 \\
(0.534) \\
\end{array}$ & $\begin{array}{l}3.710 \\
(0.650) \\
\end{array}$ & $\begin{array}{l}3.659 \\
(0.658) \\
\end{array}$ \\
\hline $\begin{array}{l}\text { Non-Manual Share of } \\
\text { Employment }\end{array}$ & & $\begin{array}{l}0.807 \\
(0.733) \\
\end{array}$ & $\begin{array}{l}0.871 \\
(0.866) \\
\end{array}$ & Professional Worker & & $\begin{array}{c}0.888 \\
(0.619) \\
\end{array}$ & $\begin{array}{c}1.118 \\
(0.622) \\
\end{array}$ \\
\hline Public Sector & & $\begin{array}{l}-0.148 \\
(0.537) \\
\end{array}$ & $\begin{array}{l}-0.081 \\
(0.728) \\
\end{array}$ & Public Sector & & $\begin{array}{c}4.623 \\
(0.647) \\
\end{array}$ & $\begin{array}{c}2.759 \\
(0.895) \\
\end{array}$ \\
\hline $\begin{array}{l}\text { Female Share of } \\
\text { Employment }\end{array}$ & & $\begin{array}{l}1.413 \\
(1.181) \\
\end{array}$ & $\begin{array}{l}1.112 \\
(1.267) \\
\end{array}$ & Female & & $\begin{array}{l}-0.621 \\
(0.582) \\
\end{array}$ & $\begin{array}{l}-1.007 \\
(0.590) \\
\end{array}$ \\
\hline $\begin{array}{l}\text { Part-time Share of } \\
\text { Employment }\end{array}$ & & $\begin{array}{l}3.403 \\
(0.899) \\
\end{array}$ & $\begin{array}{l}1.863 \\
(1.060) \\
\end{array}$ & Work Part-time & & $\begin{array}{l}-0.431 \\
(0.687) \\
\end{array}$ & $\begin{array}{l}-0.078 \\
(0.707) \\
\end{array}$ \\
\hline $\begin{array}{l}\text { Non-White Share of } \\
\text { Employment }\end{array}$ & & $\begin{array}{l}0.370 \\
(0.144) \\
\end{array}$ & $\begin{array}{l}0.090 \\
(0.169) \\
\end{array}$ & Married & & $\begin{array}{l}-2.760 \\
(0.618) \\
\end{array}$ & $\begin{array}{l}-2.791 \\
(0.618) \\
\end{array}$ \\
\hline $\begin{array}{l}\text { Skill Shortage in } \\
\text { Establishment }\end{array}$ & & $\begin{array}{l}0.671 \\
(0.433) \\
\end{array}$ & $\begin{array}{l}0.956 \\
(0.438) \\
\end{array}$ & Potential Experience & & $\begin{array}{l}-0.609 \\
(0.080)\end{array}$ & $\begin{array}{l}-0.637 \\
(0.081)\end{array}$ \\
\hline $\begin{array}{l}\text { Fewer than Five } \\
\text { Competitors }\end{array}$ & & $\begin{array}{l}-0.570 \\
(0.485) \\
\end{array}$ & $\begin{array}{l}-0.151 \\
(0.501) \\
\end{array}$ & $\begin{array}{l}\text { Potential Experience } \\
\text { Squared }\end{array}$ & & $\begin{array}{c}0.004 \\
(0.002) \\
\end{array}$ & $\begin{array}{c}0.005 \\
(0.002) \\
\end{array}$ \\
\hline $\begin{array}{l}\text { Establishment 50-99 } \\
\text { Employees }\end{array}$ & & $\begin{array}{l}1.153 \\
(0.694) \\
\end{array}$ & $\begin{array}{l}1.193 \\
(0.689) \\
\end{array}$ & Temporary Employment & & $\begin{array}{c}2.924 \\
(0.972) \\
\end{array}$ & $\begin{array}{c}2.763 \\
(0.972) \\
\end{array}$ \\
\hline $\begin{array}{l}\text { Establishment 100-199 } \\
\text { Employees }\end{array}$ & & $\begin{array}{l}0.291 \\
(0.704) \\
\end{array}$ & $\begin{array}{l}0.237 \\
(0.697) \\
\end{array}$ & Job Tenure & & $\begin{array}{l}-0.010 \\
(0.004) \\
\end{array}$ & $\begin{array}{l}-0.010 \\
(0.004) \\
\end{array}$ \\
\hline $\begin{array}{l}\text { Establishment 200-499 } \\
\text { Employees }\end{array}$ & & $\begin{array}{l}1.203 \\
(0.710) \\
\end{array}$ & $\begin{array}{l}1.291 \\
(0.710) \\
\end{array}$ & Degree & & $\begin{array}{l}11.361 \\
(1.294) \\
\end{array}$ & $\begin{array}{l}10.326 \\
(1.314) \\
\end{array}$ \\
\hline $\begin{array}{l}\text { Establishment with 500- } \\
999 \text { Employees }\end{array}$ & & $\begin{array}{l}-0.433 \\
(0.802) \\
\end{array}$ & $\begin{array}{l}-0.049 \\
(0.801) \\
\end{array}$ & Further Education & & $\begin{array}{l}13.965 \\
(1.293) \\
\end{array}$ & $\begin{array}{l}13.137 \\
(1.310) \\
\end{array}$ \\
\hline \multirow[t]{6}{*}{$\begin{array}{l}\text { Establishment with } 1000 \\
\text { or more Employees }\end{array}$} & & $\begin{array}{c}0.029 \\
(0.772) \\
\end{array}$ & $\begin{array}{c}0.313 \\
(0.769) \\
\end{array}$ & A Level & & $\begin{array}{l}10.857 \\
(1.288)\end{array}$ & $\begin{array}{l}10.174 \\
(1.300)\end{array}$ \\
\hline & & & & Apprenticeship & & $\begin{array}{l}5.245 \\
(1.422) \\
\end{array}$ & $\begin{array}{c}4.851 \\
(1.428) \\
\end{array}$ \\
\hline & & & & O Level & & $\begin{array}{l}7.507 \\
(1.242) \\
\end{array}$ & $\begin{array}{l}6.962 \\
(1.249) \\
\end{array}$ \\
\hline & & & & CSE & & $\begin{array}{l}1.778 \\
(1.645) \\
\end{array}$ & $\begin{array}{l}1.416 \\
(1.650) \\
\end{array}$ \\
\hline & & & & Other Qualification & & $\begin{array}{c}6.953 \\
(1.651) \\
\end{array}$ & $\begin{array}{l}6.415 \\
(1.658) \\
\end{array}$ \\
\hline & & & & $\begin{array}{l}\text { Workplace Size >25 } \\
\text { employees }\end{array}$ & & $\begin{array}{l}0.620 \\
(0.604) \\
\end{array}$ & $\begin{array}{c}0.711 \\
(0.611) \\
\end{array}$ \\
\hline $\begin{array}{l}\text { Industry \& Region } \\
\text { Dummies }\end{array}$ & No & No & Yes & $\begin{array}{l}\text { Industry \& Region } \\
\text { Dummies }\end{array}$ & No & No & Yes \\
\hline Log-Likelihood & -2798.1 & -2455.6 & -2434.6 & Log-Likelihood & -22292.6 & -21585.5 & -21568.3 \\
\hline Sample size & 1012 & 898 & 898 & Sample size & 34213 & 33565 & 33565 \\
\hline $\begin{array}{l}\text { Mean of Dependent } \\
\text { Variable }\end{array}$ & 2.814 & 2.746 & 2.746 & $\begin{array}{l}\text { Mean of Dependent } \\
\text { Variable }\end{array}$ & 1.218 & 1.238 & 1.238 \\
\hline Marginal Union Effect & 0.855 & 0.940 & 1.037 & Marginal Union Effect & 0.634 & 0.213 & 0.200 \\
\hline
\end{tabular}

Notes: 1. Dependent variable is the proportion of non-manual employees receiving training in the last year multiplied by the average number of days training they received.

2. Dependent variable is the number of hours training received in the last week. 
More Detailed Union Effects on Training Participation

\begin{tabular}{|c|c|c|c|c|}
\hline & \multicolumn{2}{|c|}{ Manuals } & \multicolumn{2}{|c|}{ Non-Manuals } \\
\hline & Coefficient & $\begin{array}{l}\text { Marginal } \\
\text { Effect }\end{array}$ & Coefficient & $\begin{array}{l}\text { Margina } \\
1 \text { Effect }\end{array}$ \\
\hline \multicolumn{5}{|l|}{ EMSPS } \\
\hline Recognition & $0.499(0.104)$ & 0.171 & $0.434(0.128)$ & 0.082 \\
\hline \multicolumn{5}{|l|}{ Single / Multiple Union } \\
\hline Single Union & $0.486(0.115)$ & 0.167 & $0.377(0.140)$ & 0.098 \\
\hline Multiple Union & $0.520(0.131)$ & 0.179 & $0.538(0.168)$ & 0.075 \\
\hline $\begin{array}{l}\chi^{2} \text { Test of Equality of Coefficients ( } p- \\
\text { value) }\end{array}$ & \multicolumn{2}{|l|}{$0.07(0.793)$} & \multicolumn{2}{|l|}{$0.95(0.330)$} \\
\hline \multicolumn{5}{|l|}{ Union Membership Arrangements } \\
\hline No UMA & $0.519(0.116)$ & 0.180 & $0.359(0.139)$ & 0.064 \\
\hline UMA & $0.438(0.130)$ & 0.143 & $0.560(0.170)$ & 0.130 \\
\hline $\begin{array}{l}\chi^{2} \text { Test of Equality of Coefficients ( } \mathrm{p}- \\
\text { value) }\end{array}$ & \multicolumn{2}{|l|}{$0.43(.511)$} & \multicolumn{2}{|l|}{$1.49(.222)$} \\
\hline \multicolumn{5}{|l|}{ JCC and Employee Involvement } \\
\hline No Recognition, but JCC or EI & $0.438(0.140)$ & 0.173 & $0.296(0.148)$ & 0.092 \\
\hline Recognition, but no JCC and EI & $0.531(0.180)$ & 0.196 & $0.494(0.218)$ & 0.142 \\
\hline Recognition and JCC or EI & $0.879(0.149)$ & 0.316 & $0.672(0.168)$ & 0.159 \\
\hline $\begin{array}{l}\chi^{2} \text { Test of Equality of Recognition } \\
\text { Coefficients ( } p \text {-value) }\end{array}$ & \multicolumn{2}{|l|}{$5.15(.023)$} & \multicolumn{2}{|l|}{$1.54(.214)$} \\
\hline \multicolumn{5}{|l|}{$\begin{array}{l}\text { Recognition Interacted with Size } \\
\text { Dummies }\end{array}$} \\
\hline 25-99 Employees & $0.361(0.147)$ & 0.128 & $0.529(0.180)$ & 0.114 \\
\hline 100-249 Employees & $0.527(0.168)$ & 0.178 & $0.533(0.206)$ & 0.080 \\
\hline 250 or more Employees & $0.681(0.163)$ & 0.213 & $0.209(0.203)$ & 0.021 \\
\hline $\begin{array}{l}\chi^{2} \text { Test of Equality of Coefficients (p- } \\
\text { value) }\end{array}$ & \multicolumn{2}{|l|}{$2.33(.313)$} & \multicolumn{2}{|l|}{$2.16(0.340)$} \\
\hline \multicolumn{5}{|l|}{ QLFS } \\
\hline Recognition & $0.139(0.039)$ & 0.015 & $0.199(0.022)$ & 0.051 \\
\hline \multicolumn{5}{|l|}{$\begin{array}{l}\text { Recognition Interacted with Size } \\
\text { Dummies }\end{array}$} \\
\hline Less than 25 Employees & $0.331(0.070)$ & 0.036 & $0.337(0.035)$ & 0.082 \\
\hline 25 or more Employees & $0.081(0.042)$ & 0.007 & $0.139(0.025)$ & 0.032 \\
\hline $\begin{array}{l}\chi^{2} \text { Test of Equality of Coefficients (p- } \\
\text { value) }\end{array}$ & \multicolumn{2}{|l|}{$10.59(0.010)$} & \multicolumn{2}{|l|}{$25.03(0.000)$} \\
\hline
\end{tabular}




\begin{tabular}{|c|c|c|c|c|}
\hline & \multicolumn{2}{|c|}{ Manuals } & \multicolumn{2}{|c|}{ Non-Manuals } \\
\hline & Coefficient & $\begin{array}{l}\text { Marginal } \\
\text { Effect }\end{array}$ & Coefficient & $\begin{array}{l}\text { Margina } \\
1 \text { Effect }\end{array}$ \\
\hline \multicolumn{5}{|l|}{ EMSPS } \\
\hline Recognition & $2.370(0.709)$ & 1.113 & $1.706(0.516)$ & 1.037 \\
\hline \multicolumn{5}{|l|}{ Single / Multiple Union } \\
\hline Single Union & $2.236(0.775)$ & 1.054 & $1.925(0.578)$ & 1.212 \\
\hline Multiple Union & $2.583(0.866)$ & 1.189 & $1.426(0.613)$ & 0.837 \\
\hline $\begin{array}{l}\chi^{2} \text { Test of Equality of } \\
\text { Coefficients ( } p \text {-value) }\end{array}$ & \multicolumn{2}{|l|}{$0.18(0.668)$} & \multicolumn{2}{|l|}{$0.71(0.400)$} \\
\hline \multicolumn{5}{|l|}{$\begin{array}{l}\text { Union Membership } \\
\text { Arrangements }\end{array}$} \\
\hline No UMA & $2.154(0.778)$ & 0.988 & $1.459(0.557)$ & 0.943 \\
\hline UMA & $2.466(0.833)$ & 1.217 & $2.182(0.636)$ & 1.435 \\
\hline $\begin{array}{l}\chi^{2} \text { Test of Equality of } \\
\text { Coefficients ( } p \text {-value) }\end{array}$ & \multicolumn{2}{|l|}{$0.18(0.671)$} & \multicolumn{2}{|l|}{$1.59(0.208)$} \\
\hline \multicolumn{5}{|l|}{$\begin{array}{l}\text { JCC and Employee } \\
\text { Involvement }\end{array}$} \\
\hline No Recognition, but JCC or EI & $3.149(1.041)$ & 1.286 & $2.521(0.675)$ & 1.410 \\
\hline Recognition, but no JCC and EI & $2.893(1.239)$ & 1.116 & $3.524(0.908)$ & 1.829 \\
\hline Recognition and JCC or EI & $5.164(1.063)$ & 2.180 & $3.374(0.700)$ & 1.902 \\
\hline $\begin{array}{l}\chi^{2} \text { Test of Equality of } \\
\text { Recognition Coefficients (p- } \\
\text { value) }\end{array}$ & \multicolumn{2}{|l|}{$6.14(0.014)$} & \multicolumn{2}{|l|}{$0.04(0.837)$} \\
\hline \multicolumn{5}{|l|}{$\begin{array}{l}\text { Recognition Interacted with } \\
\text { Size Dummies }\end{array}$} \\
\hline 25-99 Employees & $2.436(1.010)$ & 1.146 & $3.640(0.749)$ & 2.333 \\
\hline 100-249 Employees & $2.454(1.188)$ & 1.156 & $1.325(0.849)$ & 0.749 \\
\hline 250 or more Employees & $2.230(1.050)$ & 1.037 & $-0.033(0.718)$ & -0.017 \\
\hline $\begin{array}{l}\chi^{2} \text { Test of Equality of } \\
\text { Coefficients ( } p \text {-value) }\end{array}$ & \multicolumn{2}{|l|}{$0.02(0.982)$} & \multicolumn{2}{|l|}{$7.02(0.001)$} \\
\hline \multicolumn{5}{|l|}{ QLFS } \\
\hline Recognition & $6.475(1.624)$ & 0.169 & $3.659(0.658)$ & 0.200 \\
\hline \multicolumn{5}{|l|}{$\begin{array}{l}\text { Recognition Interacted with } \\
\text { Size Dummies }\end{array}$} \\
\hline Less than 25 Employees & $9.766(2.988)$ & 0.294 & $5.219(1.060)$ & 0.522 \\
\hline 25 or more Employees & $5.501(1.788)$ & 0.143 & $2.968(0.752)$ & 0.275 \\
\hline
\end{tabular}


TABLE 6

Other Training Measures

\begin{tabular}{||l|l|l|l|l||}
\hline & $\begin{array}{l}\text { Sample } \\
\text { Size }\end{array}$ & $\begin{array}{l}\text { Proportion of } \\
\text { Establishments } \\
\text { with Training } \\
\text { Centre/Budget/ } \\
\text { Plan }\end{array}$ & $\begin{array}{l}\text { Recognition } \\
\text { Coefficient } \\
\text { (Standard } \\
\text { Error) }\end{array}$ & $\begin{array}{l}\text { Margin } \\
\text { al Effect }\end{array}$ \\
\hline $\begin{array}{l}\text { Training Centre or School } \\
\text { Covering Employees at } \\
\text { Establishment }\end{array}$ & 1232 & 0.563 & $0.441(0.103)$ & 0.173 \\
\hline $\begin{array}{l}\text { Training Budget Which } \\
\text { Covers the Establishment }\end{array}$ & 1440 & 0.544 & $0.063(0.096)$ & 0.024 \\
\hline $\begin{array}{l}\text { Training Plan Which } \\
\text { Covers the Establishment }\end{array}$ & 1440 & 0.538 & $0.285(0.093)$ & 0.113 \\
\hline
\end{tabular}




\section{REFERENCES}

Arulamplam, W., Booth, A. and Elias, P. (1995) ‘Count Data Models of Work-Related Training: A Study of Young Men in Britain', University of Essex mimeo.

Bird, J. (1990) 'Membership of Trade Unions in 1988', Employment Gazette, May, pp.259-62.

Blanchflower, D. (1986) 'What Effect Do Unions Have on Relative Wages in Great Britain?', British Journal of Industrial Relations, 24, pp.195-204.

Blundell, R., Dearden, L. and Meghir, C. (1995) 'The Determinants and Effects of WorkRelated Training in Britain', Institute for Fiscal Studies, mimeo.

Booth, A. (1991) 'Job-Related Formal Training: Who Receives it and What is it Worth?', Oxford Bulletin of Economics and Statistics, 53, pp.281-294.

CEDEFOP (1987a) The Role of the Social Partners in Vocational Training and Further Training in the Federal Republic of Germany', Berlin, CEDEFOP.

CEDEFOP (1987b) 'The Role of Unions and Management in Vocational Training in France', Berlin, CEDEFOP.

Claydon, T. and Green, F. (1994) 'Can Trade Unions Improve Training in Britain?', Personnel Review, 23, pp.37-51.

Corcoran, L. and Wareing, A. (1994) 'Trade Union Recognition: Data From the 1993 Labour Force Survey', Department of Employment, Employment Gazette, December, pp.441-451.

Crouch, C. (1992) 'The Dilemmas of Vocational Training Policy: Some Comparative Lessons', Policy Studies, 13, pp.33-48.

Dench, S. (1993a) 'What Types of Employer Train?', Employment Department, Social Science Research Branch Working Paper No.3.

Dench, S. (1993b) 'Employers' Training: Its Infrastructure and Organisation', Employment Department, Social Science Research Branch Working Paper No.4.

Dench, S. (1993c) 'Employers' Provision of Continuous Training', Employment Department, Social Science Research Branch Working Paper No.6.

Disney, R., Gosling, A. and Machin, S. (1995) 'British Unions in Decline: Determinants of the 1980s Fall in Trade Union Recognition', Industrial and Labor Relations Review, 48, pp.403-19. 
Duncan, G. and Stafford, F. (1980) 'Do Union Members Receive Compensating Differentials', American Economic Review, 70, pp.355-71.

Elias, P. (1994) 'Job-Related Training, Trade Union Membership, and Labour Mobility: A Longitudinal Study', Oxford Economic Papers, 46, pp.563-578.

Finegold, D. and Soskice, D. (1988) 'Britain's Failure to Train: Explanations and Possible Strategies', Oxford Review of Economic Policy, 4, pp.21-53.

Freeman, R. and Medoff, J. (1984) What do Unions Do?, New York: Basic Books.

Green, F. (1993a) 'The Impact of Trade Union Membership on Training in Britain', Applied Economics, 25, pp.1033-43.

Green, F. (1993b) 'The Determinants of Training of Male and Female Employees in Britain', Oxford Bulletin of Economics and Statistics, 55(1), pp.103-122.

Green, F., Hoskins, M. and Montgomery, S. (1996 forthcoming) 'The Effects of Training, Further Education and YTS on the Earnings of Young Employees', Oxford Bulletin of Economics and Statistics, 58.

Green, F., Machin, S. and Wilkinson, D. (1995) 'Unions and Training: An Analysis Of Training Practices in Unionised and Non-Unionised Workplaces', Discussion Paper E95/08, School of Business and Economic Studies, University of Leeds.

Greenhalgh, C. and Mavrotas, G., (1994) 'The Role of Career Aspirations and Financial Constraints in Individual Access to Vocational Training', Oxford Economic Papers, 46, pp.579-604.

Heyes, J. (1993) 'Training Provision and Workplace Institutions: An Investigation', Industrial Relations Journal, 24, pp.296-307.

Kennedy, S., Drago, R., Sloan, J. and Wooden, M. (1994) 'The Effect of Trade Unions on the Provision of Training: Australian Evidence', British Journal of Industrial Relations, 32, pp.565-580.

Koike, K. and Inoki, T., eds, (1990) Skill Formation in Japan and Southeast Asia, University of Tokyo Press: Tokyo.

Labour Research Department, (1990) ‘Bargaining Report', January.

Lynch, L. (1992) 'Private Sector Training and the Earnings of Young Workers', American Economic Review, 82, pp.299-312.

Machin, S. and Stewart, M. (1996) 'Trade Unions and Financial Performance', forthcoming Oxford Economic Papers. 
Machin, S., Stewart, M. and Van Reenen, J. (1993) 'The Economic Effects of Multiple Unionism: Evidence From the 1984 Workplace Industrial Relations Survey', Scandinavian Journal of Economics Performance.

Mason, G., Prais, S. and van Ark, B. (1992) 'Vocational Education and Productivity in the Netherlands and Britain', National Institute Economic Review, 140, pp.45-63.

Metcalf, D. (1991) 'British Unions: Dissolution or Resurgence', Oxford Review of Economic Policy, 7(1), pp.18-32.

Millward, N., Stevens, M., Smart, D. and Hawes, W. (1992) Workplace Industrial Relations in Transition: the ED/ESRC/PSI/ACAS Surveys, Aldershot: Dartmouth.

Mincer, J., (1983) 'Union Effects: Wages, Turnover and Job Training' in New Approaches to Labor Unions, JAI Press.

Osterman, P. (1995) 'Skill, Training and Work Organisation in American Establishments', Industrial Relations, 34(2), pp.125-146.

Ryan, P. (1991) 'Information Costs, Training Quality and Trainee Exploitation', Cambridge University mimeo, July.

Stewart, M. (1987) 'Collective Bargaining Arrangements, Closed Shops and Relative Pay', Economic Journal, 97, pp.140-56.

Stewart, M. (1995) 'Union Wage Differentials in an Era of Declining Unionisation', Oxford Bulletin of Economics and Statistics, 57, pp.143-66.

Streeck, W. (1989) 'Skills and the Limits of Neo-liberalism: The Enterprise of the Future as a Place of Learning', Work, Employment and Society, 3(1), pp.89-104.

Stuart, M. (1994) 'Training in the Printing Industry: An Investigation Into the Recruitment, Training and Retraining Agreement', Human Resource Management Journal, 4(3), pp.62-78.

Trades Union Congress, (1991) Collective Bargaining Strategy for the 1990s, TUC: London.

Veum, J. (1995) 'Source of Training and their Impact on Wages', Industrial and Labor Relations Review, 48, pp.812-26.

Waddington, J. (1992) 'Trade Union Membership in Britain 1980-87: Unemployment and Restructuring', British Journal of Industrial Relations, 30, pp.287-324. 
Winterton, J. and Winterton, R. (1994) 'Collective Bargaining and Consultation Over Continuing Vocational Training', Research Strategy Branch, Employment Department: Sheffield. 